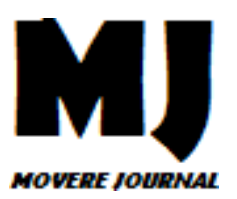

Movere Journal Vol 3 No. 2 Juli 2021 Hal 233 - 246

MOVERE JOURNAL

http://ojs.stie-tdn.ac.id/index.php/mv

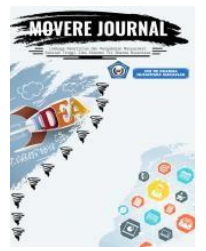

\title{
Pengaruh Kepemimpinan Dan Motivasi Terhadap Kinerja Karyawan Pada PT. Jasa Raharja Cabang Sulawesi Selatan
}

\author{
Syahrani Amalia', Ady Andardinata ${ }^{2}$, Andi Rifqah Purnama Alam ${ }^{3}$ \\ Sekolah Tinggi Ilmu Ekonomi Tri Dharma Nusantara ${ }^{1,2,3}$ \\ Email : \\ Syahraniamalia8@gmail.com \\ adyandardinata173@gmail.com \\ andirifqah.alam@gmail.com
}

\begin{abstract}
Abstrak :
Penelitian ini bertujuan untuk: (1) Untuk mengetahui pengaruh langsung kepemimpinan terhadap kinerja karyawan pada PT. Jasa Raharja Cabang Sulawesi Selatan, (2) Untuk mengetahui pengaruh langsung motivasi terhadap kinerja karyawan pada PT. Jasa Raharja Cabang Sulawesi Selatan, dan (3) Untuk mengetahui pengaruh secara simultan kepemimpinan dan motivasi terhadap kinerja karyawan pada PT. Jasa Raharja Cabang Sulawesi Selatan. Hasil perhitungan untuk (1) regresi berganda diperoleh nilai $\mathrm{Y}=5,272+$ $0,375 \mathrm{X}_{1}+0,498 \mathrm{X}_{2}$, (2) nilai uji koefisien korelasi $(\mathrm{R})$ sebesar 0,770 dan uji koefisien determinasi $\left(\mathrm{R}^{2}\right)$ sebesar 0,592. Selanjutnya (3) untuk uji-t pada variabel kepemimpinan terhadap kinerja baerpengaruh positif dan signifikan dengan perolehan nilai $\mathrm{t}$ hitung $>\mathrm{t}$ tabel $(2,226>1,697)$ dengan sig. $(0,034<0,05)$ sehingga dinyatakan $\mathrm{H}_{01}$ ditolak dan $\mathrm{Ha}_{1}$ diterima. Sementara untuk variabel motivasi terhadap kinerja diperoleh nilai $\mathrm{t}$ hitung $>\mathrm{t}$ tabel $(2,740>1,697)$ dengan sig. $(0,010<0,05)$. Sedangkan $(4)$ perhitungan nilai uji $\mathrm{f}$ diperoleh $\mathrm{F}$ hitung > F tabel $(21,809>3,32)$ dengan sig. $(0,000<0,05)$ sehingga kepemimpinan dan motivasi secara simultan berpengaruh positif dan signifikan terhadap kinerja karyawan, maka dinyatakan $\mathrm{H}_{02}$ ditolak dan $\mathrm{Ha}_{2}$ diterima, artinya terdapat pengaruh motivasi terhadap kinerja karyawan. Dengan demikian hipotesis yang diajukan dalam penelitian ini diterima.
\end{abstract}

Kata kunci: Kepemimpinan, motivasi dan kinerja.

\begin{abstract}
:
The purpose of this study: (1) To determine the direct influence of leadership on employee performance at PT. Jasa Raharja South Sulawesi Branch, (2) To determine the direct effect of motivation on employee performance at PT. Jasa Raharja South Sulawesi Branch, and (3) To determine the simultaneous influence of leadership and motivation on employee performance at PT. Jasa Raharja South Sulawesi Branch. The calculation results for (1) multiple regression obtained the value of $Y=5.272+0.375 X_{1}+0.498 X_{2}(2)$ the correlation coefficient test value $(R)$ is 0.770 and the coefficient of determination test $\left(R^{2}\right)$ is 0.592 . Furthermore (3) for the $t$-test on the variable leadership on performance has a positive and significant effect with the acquisition of the value of $t$ count $>t$ table $(2.226>1.697)$ with sig $(0.034<0.05)$ so that $H_{01}$ is rejected and $\mathrm{Ha}_{1}$ is accepted. Meanwhile, for the motivation variable on performance, the value of $t$ count $>$ t table $(2,740>1,697)$ with sig $(0.010<0.05)$ is obtained. Meanwhile, (4) the calculation of the value of the $f$ test is obtained by $F$ arithmetic $>F$ table $(21.809>3.32)$ with sig. $(0.000<0.05)$ so that leadership and
\end{abstract}


motivation simultaneously have a positive and significant effect on employee performance, it is stated that $\mathrm{H}_{02}$ is rejected and $\mathrm{Ha}_{2}$ is accepted, meaning that there is an influence of motivation on employee performance. Thus, the hypothesis proposed in this study is accepted as.

Keywords: Leadership, motivation and performance.

\section{A. PENDAHULUAN}

\section{Latar Belakang}

Pada dasarnya manusia tidak dapat lepas dari tanggungjawab dalam kesehariannya atau dalam kehidupannya, ia selalu melakukan pengelolaan waktunya, dirinya dan keluarganya untuk memenuhi kebutuhan atau tujuan yang diinginkan. Tentunya dibutuhkan oleh semua makhluk sosial untuk memberikan kemudahan dalam pencapaian tujuan, menjaga keseimbangan di antara tujuan-tujuan yang saling bertentangan serta mencapai tujuan yang efektif dan efisien dalam suatu kegiatan dengan rangkaian untuk mencapai suatu tujuan.

Perkembangan dan perubahan dalam perusahaan akan selalu berkembang untuk mempertahankan keberadaannya. Segala sesuatu yang semula tidak terhubung satu sama lainnya lalu diintegrasikan dihimpun menjadi suatu sistem, terkoordinasi, kooperatif dengan maksud tujuan organisasi tercapai melalui pembagian tugas dan tanggungjawab yang adil. Tentunya ada proses yang harus dijalani dalam menentukan keberhasilan. Di era globalisasi tentu sarana transportasi merupakan kebutuhan paling penting dalam melakukan segala kegiatan-kegiatannya. Dalam hal perkembangan ilmu pengetahuan dan teknologi khususnya pada bidang lalu lintas dan transportasi yang memberikan manfaat positif pada setiap kegiatan manusia dan tidak lepas juga manfaat negatif yang berdampak buruk di bidang lalu lintas seperti kecelakaan lalu lintas.

Kedudukan seperti inilah yang menjadi keharusan bahwa setiap warga negara harus mendapatkan perlindungan dari kerugian yang diderita, khususnya risiko yang diakibatkan kecelakaan lalu lintas oleh Negara. Hal inilah yang menjadikan pemerintah memberikan kepercayaan pada PT. Jasa Raharja untuk memberikan santunan kepada korban lalu lintas baik pengguna kendaraan dan penumpang umum berdasarkan UU Nomor 33 Tahun 1964 tentang mengelola dan menyelenggarakan pelaksanaan Dana Wajib Kecelakaan dan UU Nomor 34 Tahun 1964 mengelola dan menyelenggarakan pelaksanaan Dana Wajib kecelakaan Lalu Lintas Jalan.

Dalam rangka meringankan beban yang ditanggung korban kecelakaan lalu lintas maka perusahaan milik negara PT. Jasa Raharja mendirikan kantor cabang-cabang di berbagai daerah agar bisa terus berusaha setiap saat upaya membantu korban dimana saja dan salah satunya adalah di kota Makassar didirikan perusahaan PT. Jasa Raharja Cabang Sulawesi Selatan.

Adapun keberhasilan suatu perusahaan untuk menduduki posisi teratas merupakan campur tangan sumber daya manusia yang berkualitas. Perusahaan memerlukan dorongan dari seorang pemimpin untuk para bawahannya agar mampu menciptakan kinerja yang baik agar mencapai tujuan. Maka dengan pemimpin yang cakap juga terbentuklah kerja sama di dalam kelompok untuk mencapai tujuan perusahaan/organisasi secara efektif dan efisien.

Salah satu pemenuhan agar mencapai tujuan ialah pemberian motivasi. Motivasi adalah dorongan yang timbul pada diri seseorang secara sadar atau tidak sadar untuk melakukan suatu tindakan dengan tujuan tertentu. Motivasi juga muncul dari interaksi seseorang dengan situasi yang terjadi. Dengan adanya motivasi yang tinggi maka kinerja karyawan akan baik.

Kinerja merupakan tolok ukur pencapaian seseorang dalam melaksanakan pekerjaannya. Oleh karena itu, penilaian kinerja ini menjadi pegangan untuk para karyawan agar tetap bekerja dengan efektif dan 
efisien demi tujuan bersama. Sehingga menumbuhkan semangat baru dalam budaya kerja di perusahaan atau organisasi di mana kita bekerja.

Berdasarkan uraian di atas, maka penulis tertarik untuk melakukan penelitian dengan judul "Pengaruh Kepemimpinan dan Motivasi terhadap Kinerja PT. Jasa Raharja Cabang Sulawesi Selatan"

\section{Rumusan Masalah}

Adapun rumusan masalah dalam penelitian ini, adalah

a) Apakah kepemimpinan berpengaruh langsung terhadap kinerja karyawan pada PT. Jasa Raharja Cabang Sulawesi Selatan?

b) Apakah motivasi berpengaruh langsung terhadap kinerja karyawan PT. Jasa Raharja Cabang Sulawesi Selatan?

c) Apakah kepemimpinan dan motivasi berpengaruh secara simultan terhadap kinerja karyawan PT. Jasa Raharja Cabang Sulawesi Selatan?

3. Tujuan dan Manfaat Penelitian ?

Tujuan Penelitian Adapun tujuan penelitian ini berdasarkan rumusan masalah sebagaimana, yaitu:

a) Untuk mengetahui pengaruh kepemimpinan terhadap kinerja karyawan PT. Jasa Raharja Cabang Sulawesi Selatan.

b) Untuk mengetahui pengaruh motivasi terhadap kinerja karyawan PT. Jasa Raharja Cabang Sulawesi Selatan.

c) Untuk mengetahui pengaruh kepemimpinan dan motivasi terhadap kinerja karyawan PT. Jasa Raharja Cabang Sulawesi Selatan.

Adapun manfaat penelitian adalah:

a) Bagi Instansi, Perusahaan dapat memperkenalkan masyarakat tentang kondisi perusahaan dan kebutuhannya akan Sumber Daya Manusia (SDM) yang profesional dan pertimbangan pengambilan kebijakan dalam mengelola perusahaan terutama berkaitan dengan kinerja karyawan yang dipengaruhi oleh kepemimpinan dan motivasi

b) Bagi Institusi, Menjadi tolok ukur untuk mengetahui sejauh mana kemampuan mahasiswa dalam menyerap ilmu yang telah didapatkan selama perkuliahan dan pengaplikasian kerja sama yang baik antara PT.Jasa Raharja Cabang Sulawesi Selatan dengan STIE Tri Dharma Nusantara Makassar

c) Bagi Peneliti Lain, Untuk menjadi bahan perbandingan bagi peneliti terdahulu dan sumber referensi penelitian selanjutnya yang akan mengembangkan penelitian ini khususnya manajemen sumber daya manusia.

\section{B. TINJAUAN PUSTAKA}

1. Pengertian Kepemimpinan

Menurut Ganyang

(2018:157)

"kepemimpinan adalah kemampuan seseorang untuk mengarahkan dan mempengaruhi tingkah laku orang lain melalui proses komunikasi yang efektif untuk mencapai tujuan individu, kelompok, dan perusahaan". Sedangkan Hasibuan (2018:170) berpendapat bahwa kepemimpinan adalah cara seorang pemimpin mempengaruhi perilaku bawahan, agar mau bekerja sama dan bekerja secara produktif untuk mencapai tujuan organisasi

Busro (2018:215) mengatakan kepemimpinan adalah "serangkaian kegiatan atau aktivitas pemimpin yang terkait dengan kedudukan atau posisi serta gaya atau perilaku pemimpin itu sendiri. Kepemimpinan sebagai proses hubungan atau interaksi antar pemimpin bawahan dan dalam situasi tertentu".

Menurut Rahmat (2019:1) mengatakan kepemimpinan (leadership) yaitu kemampuan dalam memimpin, menggerakkan dan mempengaruhi perilaku orang lain untuk dapat melaksanakan tugas dan tanggung jawab 
secara baik demi mencapai tujuan tertentu. Dari beberapa pendapat ahli yang dikemukakan tentang pengertian kepemimpinan dapat disimpulkan bahwa kepemimpinan adalah kemampuan seseorang untuk mempengaruhi dan menggerakkan para bawahan dengan interaksi dan bekerja sama untuk mencapai tujuan yang baik. Kepemimpinan juga memiliki peran yang sangat penting bagi perubahan baru organisasi.

\section{Pengertian Motivasi}

Menurut Ganyang (2018:112), "motivasi adalah suatu kondisi yang mestimuli pihak lain termasuk karyawan untuk bersikap dan berperilaku dengan memanfaatkan semua potensi yang dimilikinya untuk mencapai tujuan tertentu termasuk tujuan perusahaan". Sedangkan pendapat Suparyadi (2015:417), "motivasi adalah dorongan yang disebabkan oleh suatu kebutuhan (karsa) yang menggerakkan dan mengarahkan perilaku individu guna mencapai tujuan atau insentif tertentu”. Mangkunegara (2017:93) menyatakan bahwa "motif adalah suatu dorongan kebutuhan dalam diri pegawai yang perlu dipenuhi agar pegawai tersebut dalam menyesuaikan diri terhadap lingkungannya, sedangkan motivasi adalah kondisi yang menggerakkan pegawai agar mampu mencapai tujuan dari motifnya. Selanjutnya Hasibuan (2018:143), "Motivasi adalah pemberian daya penggerak yang menciptakan kegairahan kerja seseorang agar mereka mau bekerja sama, bekerja efektif, dan terintegrasi dengan segala upayanya untuk mencapai kepuasan“.

Kesimpulan yang dapat diambil dari pengertian motivasi menurut para ahli ialah motivasi merupakan suatu penggerak dari dalam diri seseorang untuk mengerjakan hak dan tanggungjawabnya untuk mencapai tujuan organisasi serta keberhasilan suatu organisasi/perusahaan.

\section{Pengertian Kinerja}

Kasmir (2019:182) berpendapat bahwa kinerja adalah hasil kerja dan perilaku kerja yang telah dicapai dalam menyelesaikan tugastugas dan tanggung jawab yang dberikan dalam suatu periode tertentu.

Kinerja dalam bahasa Inggris disebut dengan job performance atau actual performance atau level of performance, yang merupakan tingkat keberhasilan pegawai dalam menyelesaikan pekerjaannya. "Kinerja merupakan perwujudan dari kemampuan bentuk karya nyata serta hasil kerja yang dicapai pegawai dalam mengemban tugas dan pekerjaan yang berasa dari organisasi" (Donni 2016:269).

Selanjutnya menurut Mulyadi (2015:63), "kinerja adalah hasil kerja yang dicapai oleh pekerja atau karyawan sebagai kualitas dan kuantitas yangs sesuai dengan tugas dan tanggung jawab mereka". Sedangkan menurut Mangkunegara $(2016 ; 67)$ "kinerja adalah hasil kerja secara kualitas dan kuantitas yang dicapai oleh suatu pegawai dalam melaksanakan tugasnya sesuai dengan tanggung jawab yang diberikan kepadanya". Sehingga dapat kinerja diartikan sebagai suatu dorongan semangat dari dalam diri seseorang untuk mengerjakan sesuau agar mencapai tujuan.

\section{Pengaruh Kepemimpinan, Motivasi dan Kinerja}

a. Pengaruh Kepemimpinan dengan Kinerja

Menurut Kasmir $\quad$ (2019:191) kepemimpinan merupakan perilaku seorang pemimpin dalam mengatur, mengelola dan memerintah bawahannya untuk mengerjakan tugas dan tanggung jawab yang diberikan untuk meningkatkan kinerja karyawannya.

Pendapat di atas dapat disimpulkan bahwa kepemimpinan merupakan peran yang sangat penting dalam memberikan arahan agar lebih termotivasi dalam melakukan pekerjaannya sehingga menghasilkan tujuan yang baik.

b. Pengaruh Motivasi dengan Kinerja 
Pada hakikatnya hasil kinerja yang tinggi merupakan hasil dari motivasi yang tinggi, begitu juga sebaliknya apabila motivasi rendah maka kinerja akan rendah. Menurut Ganyang (2019:112), "motivasi adalah suatu kondisi yang menstimuli pihak lain termasuk karyawan untuk bersikap dan berperilaku dengan memanfaatkan semua potensi yang dimilikinya untuk mencapai tujuan tententu termasuk tujuan perusahaan".

Motivasi merupakan salah satu faktor peningkatan kinerja karyawan, motivasi yang tepat tentu akan mendorong gairah karyawan untuk memaksimalkan hasil pekerjaanya, karena apabila suatu perusahaan berhasil mencapai

\section{Hipotesis}

Berdasarkan landasan teori, penelitian terdahulu dan kerangka pikir, hipotesis dalam penelitian ini adalah sebagai berikut

$\mathrm{H}_{1}$ : Kepemimpinan berpengaruh positif signifikan terhadap kinerja pegawai pada PT. Jasa Raharja Cabang Sulawesi Selatan.

$\mathrm{H}_{2}$ : Motivasi berpengaruh positif signifikan terhadap kinerja pegawai pada PT. Jasa Raharja Cabang Sulawesi Selatan.

$\mathrm{H}_{3}$ : Kepemimpinan dan Motivasi berpengaruh positif secara simultan terhadap kinerja pegawai pada PT. Jasa Raharja Cabang Sulawesi Selatan.

\section{METODE PENELITIAN}

\section{Lokasi dan Waktu Penelitian}

Lokasi penelitian ini dilakukan di perusahaan PT. Jasa Raharja Cabang Sulawesi Selatan yang beralamat di Jalan Dr. Ratulangi No.77 Kota Makassar, Sulawesi Selatan. Waktu penelitian ini dilakukan selama tiga bulan. Penelitian ini dimulai dari 12 tujuannya maka pemenuhan karyawan akan terjamin.

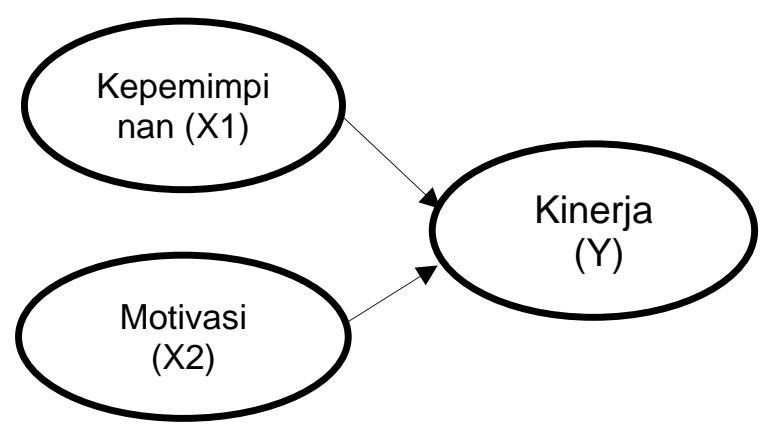

Keterangan:

- = Pengaruh langsung

$----\quad=$ Pengaruh simultan

Sumber: Penulis, 2021

November 2020 sampai dengan 12 Februari 2021.

\section{Jenis dan Sumber Data}

Adapun data yang digunakan dalam penelitian ini terdiri dari data kualitatif dan data kuantitatif:

a. Data kualitatif, Data yang disajikan dalam bentuk kata verbal bukan dalam bentuk angka, yang termasuk data kualitatif dalam penelitian ini yaitu gambaran umum objek penelitian

b. Data kuantitatif, Jenis data yang dapat diukur dan dihitung secara langsung yang berupa informasi atau penjelasan yang dinyatakan dengan bilangan atau angka-angka, dalam hal ini data kuantitatif yang diperlukan adalah; jumlah karyawan, jenis kelamin, usia, pendidikan, dan masa kerja.

Sumber data yang digunakan dalam penelitian ini terdiri dari dua sumber, yaitu:

a. Data primer, Data yang diperoleh langsung dari responden yang menjadi subjek dalam penelitian. 
b. Data sekunder, Data pendukung yang diperoleh dari tempat penelitian, jurnal, buku-buku literature dan dokumen lainnya yang ada hubungannya dengan masalah penelitian.

\section{Teknik pengumpulan data}

Adapun teknik pengumpulan data yang dilaksanakan dalam penelitian ini yakni:

a. Observasi, Observasi dilakukan dengan pihak PT. Jasa Raharja Cabang Sulawesi Selatan guna mengetahui permasalahan yang terkait dalam penelitian.

b. Dokumentasi, Dokumentasi dalam hal ini berupa data-data yang berhubungan dengan penelitian seperti sejarah perusahaan, struktur organisasi, visi dan misi, serta tugas dan tanggung jawab yang telah dibagikan kepada karyawan perusahaan.

c. Kuesioner/Angket,

Kuesioner/angket berisi sejumlah pertanyaan/pernyataan yang mewakili sejumlah indikatorindikator setiap variabel penelitian. Kuesioner diberikan langsung kepada responden untuk dijawab secara jujur sesuai dengan kenyataan mereka di tempat kerja.

\section{Populasi dan Sampel}

a. Populasi, Populasi menurut Sugiyono (2017:80) merupakan wilayah generalisasi yang terdiri atas objek/subjek yang memiliki kuantitas dan karakteristik tertentu yang ditetapkan oleh peneliti untuk dipelajari dan kemudian ditarik kesimpulannya. Populasi yang diangkat dalam penelitian ini, seluruh karyawan PT. Jasa Raharja Cabang Sulawesi Selatan sebanyak 34 orang.

b. Sampel, Menurut Sugiyono (2017:81) sampel adalah bagian dari jumlah dan karakteristik yang dimiliki populasi tersebut. Sampel dalam penelitian ini adalah karyawan PT. Jasa Raharja Cabang Sulawesi Selatan.

Dalam penelitian ini menggunakan teknik sampling jenuh yang dimana teknik penentuan sampel semua anggota populasi digunakan sebagai sampel. Adapun responden yang digunanakan sebanyak 33 orang karyawan PT. Jasa Raharja Cabang Sulawesi Selatan tidak termasuk pimpinan.

\section{Hasil dan Pembahasan}

\section{Karakteristik responden}

a. Karakteristik berdasarkan jenis kelamin

responden

Jumlah jenis kelamin dalam karakteristik responden dapat dilihat pada tabel berikut:

Tabel 5: Jumlah responden menurut jenis kelamin

\begin{tabular}{|c|c|c|c|}
\hline No & Jenis Kelamin & Jumlah (Orang) & Persentase (\%) \\
\hline 1 & Laki-laki & 21 & 63,64 \\
\hline 2 & Perempuan & 12 & 36,36 \\
\hline & Jumlah & 33 & 100 \\
\hline
\end{tabular}

Sumber: Data diolah, 2021

Berdasarkan tabel tersebut, menunjukkan bahwa dari 33 orang

jumlah responden yang berjenis kelamin laki-laki berjumlah 21 orang atau sebesar $63,64 \%$ dan 
jumlah jenis kelamin perempuan 12 orang atau sebesar $36,36 \%$. b. Karakteristik berdasarkan tingkat usia

Tabel 6: Jumlah responden menurut tingkat usia

\begin{tabular}{|c|c|c|}
\hline Umur & Jumlah (Orang) & Persentase (\%) \\
\hline $20-30$ & 18 & 54,55 \\
\hline $31-40$ & 10 & 30,30 \\
\hline $41-50$ & 2 & 6,06 \\
\hline$>50$ & 3 & 9,09 \\
\hline Jumlah & 33 & 100 \\
\hline
\end{tabular}

Sumber:Data diolah, 2021

Berdasarkan dari tabel 6, menunjukkan bahwa dari 33 orang jumlah responden terdapat umur antara 20-30 tahun sebanyak 18 orang atau sebanyak $54,55 \%$, umur antara 31-40 tahun sebanyak 10 orang atau $30,30 \%$, umur antara 41 50 tahun sebanyak 2 orang atau

c. Karakteristik berdasarkan masa kerja
6,06\% dan umur lebih dari 50 tahun sebanyak 3 orang atau 9,09\%. Hal tersebut menunjukkan bahwa umumnya responden PT. Jasa Raharja Cabang Sulawesi Selatan didominasi oleh karyawan usia produktif.

Tabel 7: Jumlah responden menurut masa kerja

\begin{tabular}{|c|c|c|}
\hline Masa Kerja & Jumlah (Orang) & Persentase (\%) \\
\hline $1-5$ & 17 & 51,52 \\
\hline $6-10$ & 6 & 18,18 \\
\hline$>10$ & 10 & 30,30 \\
\hline Jumlah & 33 & 100 \\
\hline
\end{tabular}

Sumber:Data diolah, 2021

Berdasarkan tabel tersebut menunjukkan bahwa dari 33 orang jumlah responden yang masa kerja 1-5 tahun sebanyak 17 orang atau $51,52 \%$, masa kerja 6-10 tahun sebanyak 6 orang atau $18,18 \%$, dan masa kerja .diatas 10 tahun sebanyak 10 orang atau 30,30\%. Hal tersebut menunjukkan bahwa umumnya responden masa kerja 1-5 tahun lebih banyaknya karyawan yang berusia muda dari pada masa kerja 6-10 tahun dan lebih dari 10 tahun. 
d. Karakteristik berdasarkan pendidikan

Tabel 8: Jumlah responden menurut pendidikan

\begin{tabular}{|c|c|c|}
\hline Tingkat Pendidikan & Jumlah (Orang) & Persentase (\%) \\
\hline S2 & 3 & 9,09 \\
\hline S1 & 30 & 90,91 \\
\hline Jumlah & 33 & 100 \\
\hline
\end{tabular}

Sumber : Data diolah, 2021

Berdasarkan tabel 8, menunjukkan bahwa dari 33 orang jumlah responden terdapat tingkat pendidikan strata dua (S2) sebanyak 3 orang atau sebesar $9,09 \%$, dan pada tingkat strata satu (S1) sebanyak 30 orang atau sebesar 90,91\%. Hal tersebut menunjukkan bahwa umumnya karyawan pada PT. Jasa Raharja Cabang Sulawesi Selatan sesuai dengan yang dibutuhkan perusahaan.

\section{Uji Validitas}

Pengujian validitas pada penelitian ini menggunakan Pearson Correlation dengan bantuan SPSS 25 dengan cara mengkorelasikan masing-masing skor item dan total skor item hingga diperbandingkan dengan nilai $r$ hitung $>\mathrm{r}$ tabel maka dikatakan valid.

Tabel 9 : Hasil uji validitas

\begin{tabular}{|c|l|l|l|l|}
\hline \multirow{5}{*}{ Variabel } & Item & R hitung & R tabel & $\begin{array}{c}\text { Kesimpul } \\
\text { an }\end{array}$ \\
\hline \multirow{5}{*}{ Kepemimpinan } & $\mathrm{X} 1.1$ & 0,765 & 0,344 & Valid \\
\cline { 2 - 5 } & $\mathrm{X} 1.2$ & 0,867 & 0,344 & Valid \\
\cline { 2 - 5 } & $\mathrm{X} 1.3$ & 0,831 & 0,344 & Valid \\
\cline { 2 - 5 } & $\mathrm{X} 1.4$ & 0,728 & 0,344 & Valid \\
\cline { 2 - 5 } & $\mathrm{X} 1.5$ & 0,793 & 0,344 & Valid \\
\cline { 2 - 5 } & $\mathrm{X} 1.6$ & 0,623 & 0,344 & Valid \\
\cline { 2 - 5 } & $\mathrm{X} 1.7$ & 0,638 & 0,344 & Valid \\
\cline { 2 - 5 } & $\mathrm{X} 1.8$ & 0,81 & 0,344 & Valid \\
\cline { 2 - 5 } & $\mathrm{X} 1.9$ & 0,723 & 0,344 & Valid \\
\cline { 2 - 5 } & $\mathrm{X} 1.10$ & 0,823 & 0,344 & Valid \\
\hline
\end{tabular}




\begin{tabular}{|c|c|c|c|c|}
\hline \multirow{10}{*}{ Motivasi } & $\mathrm{X} 2.1$ & 0,78 & 0,344 & Valid \\
\hline & X2.2 & 0,748 & 0,344 & Valid \\
\hline & $\mathrm{X} 2.3$ & 0,704 & 0,344 & Valid \\
\hline & X2.4 & 0,536 & 0,344 & Valid \\
\hline & $X 2.5$ & 0,688 & 0,344 & Valid \\
\hline & X2.6 & 0,78 & 0,344 & Valid \\
\hline & $\mathrm{X} 2.7$ & 0,427 & 0,344 & Valid \\
\hline & $\mathrm{X} 2.8$ & 0,823 & 0,344 & Valid \\
\hline & X2.9 & 0,848 & 0,344 & Valid \\
\hline & $\mathrm{X} 2.10$ & 0,882 & 0,344 & Valid \\
\hline \multirow{10}{*}{ Kinerja } & Y.1 & 0,696 & 0,344 & Valid \\
\hline & Y.2 & 0,919 & 0,344 & Valid \\
\hline & Y.3 & 0,756 & 0,344 & Valid \\
\hline & Y.4 & 0,799 & 0,344 & Valid \\
\hline & Y.5 & 0,898 & 0,344 & Valid \\
\hline & Y.6 & 0,941 & 0,344 & Valid \\
\hline & Y.7 & 0,756 & 0,344 & Valid \\
\hline & Y.8 & 0,82 & 0,344 & Valid \\
\hline & Y.9 & 0,787 & 0,344 & Valid \\
\hline & Y.10 & 0,713 & 0,344 & Valid \\
\hline
\end{tabular}

\section{Uji Reliabilitas}

Dengan menggunakan SPSS 25 maka hasil uji reliabilitas terhadap instrumen dapat dikatakan reliabel jika memberikan nilai Cronbachs Alpha () lebih besar dari 0,60. Berikut hasil uji reliabilitas dalam bentuk tabel:

Tabel 10: Hasil Uji Reliabilitas

\begin{tabular}{|c|c|c|c|}
\hline Variabel & $\begin{array}{c}\text { Koefisien } \\
\text { Realibilitas }\end{array}$ & $\begin{array}{c}\text { Nilai Batas Alpha } \\
(\boldsymbol{\alpha})\end{array}$ & Keputusan \\
\hline $\mathrm{X} 1$ & 0,917 & 0,6 & Relibel \\
\hline $\mathrm{X} 2$ & 0,892 & 0,6 & Relibel \\
\hline $\mathrm{Y}$ & 0,939 & 0,6 & Relibel \\
\hline
\end{tabular}

Sumber: Data diolah SPSS versi 25, 2021

Berdasarkan tabel 10 didapatkan nilai Cronbachs Alpha $(\alpha)$ 
pada seluruh variabel menunjukkan besarnya diatas nilai 0,60 sedangkan nilai tertinggi cronbachs alpha $(\alpha)$ adalah variabel $\mathrm{Y}$ sebesar 0,939 dan nilai terendah cronbachs alpha $(\alpha)$ adalah variabel $\mathrm{X}_{2}$ sebesar. Hal ini berarti bahwa seluruh pernyataan untuk variabel independen dan dependen adalah reliabel dan dapat disimpulkan instrumen pernyataan kuesioner menunjukkan kecocokan dalam mengukur variabel-variabel dalam model penelitian.

\section{Analisis Regresi Berganda}

Penelitian ini menggunakan analisis regresi berganda yang didapatkan dari hasil kuesioner dan diolah dengan menggunakan program SPSS. Adapun hasilnya sebagai berikut:

Tabel 11: Hasil analisis regresi berganda

\begin{tabular}{|c|c|c|c|c|c|}
\hline \multicolumn{6}{|c|}{ Coefficients ${ }^{\mathrm{a}}$} \\
\hline \multirow[b]{2}{*}{ Model } & \multicolumn{2}{|c|}{$\begin{array}{l}\text { Unstandardized } \\
\text { Coefficients }\end{array}$} & \multirow{2}{*}{$\begin{array}{c}\begin{array}{c}\text { Standardized } \\
\text { Coefficients }\end{array} \\
\text { Beta }\end{array}$} & \multirow[b]{2}{*}{$\mathrm{T}$} & \multirow[b]{2}{*}{ Sig. } \\
\hline & B & Std. Error & & & \\
\hline 1 (Constant) & 5,272 & 5,642 & & ,935 & ,357 \\
\hline KEPEMIMPINAN & ,375 & ,168 & ,372 & 2,226 &, 034 \\
\hline MOTIVASI & ,498 & ,182 & ,458 & 2,740 & ,010 \\
\hline
\end{tabular}

a. Dependent Variable: KINERJA

Sumber: Data diolah SPSS versi 25, 2021

Berdasarkan tabel 11 dapat diperoleh suatu model persamaan regresi linier berganda, dimana nilai beta diambil dari Unstandardized Coefficients sebagai berikut: $0,498 X_{2}$

$$
\begin{aligned}
& Y=a+b_{1} X_{1}+b_{2} X_{2}+e \\
& Y=5,272+0,375 X_{1}+
\end{aligned}
$$

Dari hasil perhitungan SPSS 25 dalam tabel coefficients diperoleh sebagai berikut:

a. Jika konstanta sebesar 5,272 maka variabel kepemimpinan (X1) dan motivasi (X1) adalah 0 sehingga variabel kinerja (Y) bernilai 5,272 dengan kata lain variabel-variabel yang mempengaruhi kinerja dianggap tetap.

b. Koefisien regresi variabel kepemimpinan sebesar 0,375, setiap kenaikan satuan variabel kepemimpinan maka akan mempengaruhi kinerja karyawan sebesar 0,375.

c. Koefisien regresi variabel motivasi sebesar 0,498 ketika terjadi kenaikan satuan variabel motivasi maka akan mempengaruhi kinerja karyawan sebesar 0,489.

Hasil analisis regresi berganda memberikan gambaran bahwa variabel dependen kinerja mendapatkan pengaruh positif signifikan pada variabel independen kepemimpinan dan motivasi sehingga menunjukkan pengaruh kepemimpinan dan motivasi yang berhubungan signifikan terhadap kinerja karyawan pada PT. Jasa Raharja Cabang Sulawesi Selatan. 
5. Uji Koefisien Korelasi (R) dan Uji Koefisien Determinasi $\left(\mathbf{R}^{2}\right)$

Uji koefisien korelasi $(\mathrm{R})$ dan koefisien determinasi $\left(\mathrm{R}^{2}\right)$ dilakukan guna mengetahui seberapa besar variabel independen kepemimpinan dan motivasi secara bersamaan menerangkan hasil variasi variabel

Tabel 12: Hasil uji korelasi (R) dan determinasi $\left(\mathrm{R}^{2}\right)$

Model Summary

\begin{tabular}{|l|r|r|r|r|}
\hline Model & R & \multicolumn{1}{|c|}{ R Square } & Adjusted R Square & \multicolumn{1}{|c|}{ Std. Error of the Estimate } \\
\hline 1 &, $770^{\mathrm{a}}$ &, 592 &, 565 & 3,13379 \\
\hline
\end{tabular}

a. Predictors: (Constant), MOTIVASI, KEPEMIMPINAN

Sumber: Data diolah SPSS versi 25, 2021

Berdasarkan hasil perhitungan program SPSS versi 25 tabel koefiesien korelasi dan determinasi tersebut, menunjukkan bahwa dipengaruhi nilai koefisien (R) sebesar 0,770 dan nilai koefisien determinasi $\left(\mathrm{R}^{2}\right)$ sebesar 0,592 atau $59,2 \%$. Hal ini menunjukkan bahwa besarnya pengaruh variabel kinerja disebabkan oleh variabel kepemimpinan dan motivasi pada PT. Jasa Raharja Cabang Sulawesi Selatan sebesar dependen kinerja karyawan pada PT. Jasa Raharja Cabang Sulawesi Selatan. Data hasil olah data koefisien determinasi $\left(\mathrm{R}^{2}\right)$ dapat pada tabel berikut:

Tabel 13: Hasil uji t

\begin{tabular}{|c|c|c|c|c|c|}
\hline \multicolumn{6}{|c|}{ Coefficients $^{\mathbf{a}}$} \\
\hline \multirow[b]{2}{*}{ Model } & \multicolumn{2}{|c|}{ Unstandardized Coefficients } & \multirow{2}{*}{$\begin{array}{c}\text { Standardized } \\
\text { Coefficients } \\
\text { Beta } \\
\end{array}$} & \multirow[b]{2}{*}{$\mathrm{T}$} & \multirow[b]{2}{*}{ Sig. } \\
\hline & $\mathrm{B}$ & Std. Error & & & \\
\hline $1 \quad$ (Constant) & 5,272 & 5,642 & & ,935 & 357 \\
\hline Kepemimpinan &, 375 &, 168 &, 372 & 2,226 &, 034 \\
\hline Motivasi & ,498 & , 182 & ,458 & 2,740 &, 010 \\
\hline
\end{tabular}

a. Dependent Variable: Kinerja

Sumber: Data diolah SPSS versi 25, 2021

$59,2 \%$ dan 40,8\% lainnya dipengaruhi oleh variabel lain yang tidak diteliti dalam penelitian ini.

\section{Uji T}

Uji $\mathrm{t}$ dilakukan untuk menunjukkan seberapa jauh pengaruh suatu variabel independen secara parsial dalam mempengaruhi variabel dependen. Berikut disajikan hasil uji $\mathrm{t}$ dalam tabel di bawah ini: 
a. Pengaruh kepemimpinan $\left(\mathrm{X}_{1}\right)$ terhadap kinerja (Y) pada PT. Jasa Raharja Cabang Sulawesi Selatan

Berdasarkan tabel 13 dimana nilai $\mathrm{t}$ hitung untuk variabel kepemimpinan sebesar 2,226 dengan signifikansi sebesar 0,034 dan kemudian dibandingkan dengan $\mathrm{t}$ tabel yaitu $\mathrm{n}=$ jumlah sampel sebanyak 33 dengan tingkat kesalahan $=0,05$ dan derajat bebas $\mathrm{n}-\mathrm{k}=33-3=30$ maka didapat $\mathrm{t}$ tabel sebesar 1,697. Olehnya itu nilai t hitung 2,226 > t tabel 1,697 dengan tingkat kesalahan $5 \%$ dinyatakan $\mathrm{H}_{01}$ ditolak dan $\mathrm{Ha}_{1}$ diterima. Sehingga terdapat hipotesis pengaruh kepemimpinan terhadap kinerja secara parsial ditolak.

Artinya terdapat pengaruh kepemimpinan secara signifikan terhadap kinerja karyawan pada PT. Jasa Raharja Cabang Sulawesi Selatan. Hal ini sejalan dengan hasil penelitian Burhan (2019) yaitu kepemimpinan berpengaruh secara signifikan terhadap kinerja karyawan pada PT. Pos Indonesia Makassar (PERSERO) dengan perhitungan $\mathrm{Y}=18,08+0,47 \mathrm{X}$ serta uji-t dimana $\mathrm{t}$ hitung $>\mathrm{t}$ tabel $(4,5313>1,6859)$.

b. Pengaruh motivasi $\left(\mathrm{X}_{2}\right)$ terhadap kinerja (Y) pada PT. Jasa Raharja Cabang Sulawesi Selatan

Berdasarkan tabel 12 dimana nilai $\mathrm{t}$ hitung untuk variabel motivasi sebesar 2,740 dengan signifikansi sebesar 0,010 dan kemudian dibandingkan dengan $\mathrm{t}$ tabel yaitu $\mathrm{n}=$ jumlah sampel sebanyak 33 dengan tingkat kesalahan $=0,05$ dan derajat bebas $\mathrm{n}-\mathrm{k}=33-3=30$ maka didapat $\mathrm{t}$ tabel sebesar 1,697. Olehnya itu nilai t hitung 2,740 > t tabel 1,697 dengan tingkat kesalahan 5\% dinyatakan $\mathrm{H}_{02}$ ditolak dan $\mathrm{Ha}_{2}$ diterima. Sehingga terdapat hipotesis pengaruh kepemimpinan terhadap kinerja secara parsial ditolak.

Artinya terdapat pengaruh motivasi secara signifikan terhadap kinerja karyawan pada PT. Jasa Raharja Cabang Sulawesi Selatan. hal ini sejalan dengan hasil penelitian Amidin (2019) yaitu motivasi berpengaruh positif terhadap kinerja karyawan pada PT. Tanyabudi Makassar dengan perhitungan $\mathrm{Y}=25,264+0,351 \mathrm{X}$ serta uji-t dimana $t$ hitung $>\mathrm{t}$ tabel $(2,681>1,699)$

\section{Uji F}

Uji $F$ dilakukan untuk menunjukkan apakah semua variabel independen secara simultan atau bersama-sama terhadap variabel dependen. Adapun hasilnya disajikan sebagai berikut:

a. Apabila signifikansi $<0,05$ maka Ha diterima dan $\mathrm{H}_{0}$ ditolak

b. Apabila signifikansi $>0,05$ maka $\mathrm{Ha}$ ditolak dan $\mathrm{H}_{0}$ diterima

Berdasarkan tabel hasil uji f di atas, dimana nilai $f$ hitung sebesar 21,809 dengan signifikansi $0,000<$ 0,05 dan $\mathrm{f}$ tabel sebesar 3,32.sehingga dapat disimpulkan bahwa $\mathrm{H}_{03}$ ditolak dan $\mathrm{Ha}_{3}$ diterima.

Artinya variabel kepemimpinan dan motivasi secara simultan berpengaruh signifikan terhadap kinerja karyawan PT. Jasa Raharja Cabang Sulawesi Selatan. 


\section{E. PENUTUP}

\section{Kesimpulan}

Berdasarkan hasil analisis dan pembahasan yang telah diuraikan, maka penulis menyajikan beberapa kesimpulan sebagai berikut :

a. Kepemimpinan berpengaruh signifikan terhadap kinerja karyawan pada PT. Jasa Raharja Cabang Sulawesi Selatan.

b. Motivasi berpengaruh signifikan terhadap kinerja karyawan PT. Jasa Raharja Cabang Sulawesi Selatan.

c. Kepemimpinan dan motivasi berpengaruh secara simultan dan signifikan terhadap kinerja karyawan pada PT. Jasa Raharja Cabang Sulawesi Selatan.

\section{Saran}

Berdasarkan penelitian yang telah dilakukan pada PT. Jasa Raharja Cabang Sulawesi Selatan, maka saran yang diberikan adalah:

a. Diharapkan untuk tetap mempertahankan sikap kepemimpinan ketika terjadi masalah dalam sebuah perusahaan, pemimpin selalu tegas dalam mengambil keputusan dan melakukan musyawarah untuk menindaklanjuti malah tersebut. Hal ini dinilai dari poin item kedua dan enam dari sepuluh item variabel kepemimpinan. Adapun dari hasil item variabel kepemimpinan lainnya diharapkan terus berlanjut dengan lebih baik.

b. Diharapkan untuk tetap mempertahankan agar perusahaan menyediakan piagam bagi karyawan yang berprestasi agar para karyawan lebih meningkatkan kinerja yang lebih baik. Hal ini dinilai dari poin item ketujuh dari sepuluh item variabel motivasi. Adapun dari hasil item variabel motivasi lainnya diharapkan terus berlanjut dengan lebih baik

c. Diharapkan para karyawan menanamkan dalam diri bahwa tujuan merupakan keadaan yang berbeda yang secara aktif dicari oleh seorang individu atau organisasi untuk dicapai agar kerja sama dalam tim untuk mencapai tujuan.

\section{DAFTAR PUSTAKA}

Agus, Widarjono. 2015. Analisis Multivariat Terapan. UPP STIM YKPN, Yogyakarta

Busro, Muhammad. 2018. Teori-Teori Manajemen Sumber Daya Manusia. Penerbit Prenadamedia Group, Jakarta.

Darodjat, Achmad Tubagus. 2015. KonsepKonsep Dasar Manajemen Personalia. PT Refika Aditama, Bandung.

Edison, Emron., Anwar Yohny., dan Komariyah Imas. 2018. Manajemen Sumber Daya Manusia. Alfabeta, Bandung.

Fahmi, Irham. (2017a). Manajemen Sumber Daya Manusia Teori dan Aplikasi. Alfabeta, Bandung.

(2018b). Pengantar Ilmu

Kepemimpinan. PT Rajagrafindo, Depok.

Ganyang, Machmed Tun. 2018. Manajemen Sumber Daya Manusia Konsep dan Realita. Penerbit In MEDIA, Bogor.

Ghazali, Imam. 2016. Aplikasi Analisis Multivariate dengan Program IBM SPSS 23. Badan Penerbit Universitas Diponegoro, Semarang.

Hasibuan, Malayu S.P. 2018. Manajemen Sumber Daya Manusia Edisi Revisi. Bumi Aksara Jakarta.

Kasmir. (2017a). Manajemen Sumber Daya Manusia Cetakan Ketiga. Rajawali Persada, Depok.

(2019b). Manajemen Sumber

Daya Manusia Teori dan Praktik. Rajawali Persada, Depok 
Mangkunegara. (2015a). Manajemen Sumber Daya Manusia Perusahaan. PT Remaja Rosdakarya, Bandung. (2016b). Manajemen Sumber Daya Manusia Perusahaan. PT Remaja Rosdakarya, Bandung

Martoyo Susilo. 2015. Manajemen Sumber Daya Manusia Edisi Kelima. BPFEJogyakarta, Jogyakarta.

Priansa, Donni Juni (2016a). Manajemen SDM Dalam Organisasi Publik dan Bisnis. Alfabeta, Bandung.

(2016b). Perencanaan \& Pengembangan SDM. Alfabeta, Bandung.

Rahmat. 2019. Manajemen Sumber Daya Manusia Jilid Kedua. Yayasan Ahmar Cendekia Indonesia, Takalar.

Riinawati. 2019. Pengantar Teori Manajemen Komunikasi dan Organisasi. PT. Pustaka Baru, Yogyakarta

Satrianegara, Fais. 2013. Pengembangan Manajemen Sumber Daya Manusia. Alauddin University Press, Makassar.

Sinambela, Lijan Poltak. 2018. Manajemen Sumber Daya ManusiaMembuat Tim Kerja Yang Solid Untuk Meningkatkan Kinerja. PT Bumi Aksara, Jakarta.

Sugiyono. 2017. Metode Penelitian Kuantitatif, Kualitatif, $\mathrm{R}$ dan $\mathrm{D}$. Alfabet, Bandung

Suparyadi. 2015. Manajemen Sumber Daya Manusiai. CV. Andi Offset, Yogyakarta.

Sutrisno, Edy. 2019. Manajemen Sumber Daya Manusia. Prenadamedia Group (Kencana), Jakarta.

Suwatno dan Priansa, Donni Juni. 2018. Manajemen SDM Dalam Organisasi Publik dan Bisnis. Alfabeta, Bandung.

Uno, Hamzah B. 2016. Teori Motivasi dan Pengukurannya. Bumi Aksara, Jakarta

Wibowo. 2016. Manajemen Kinerja Edisi Kelima. Rajawali Pers, Jakarta. 